3908000701534 ? 


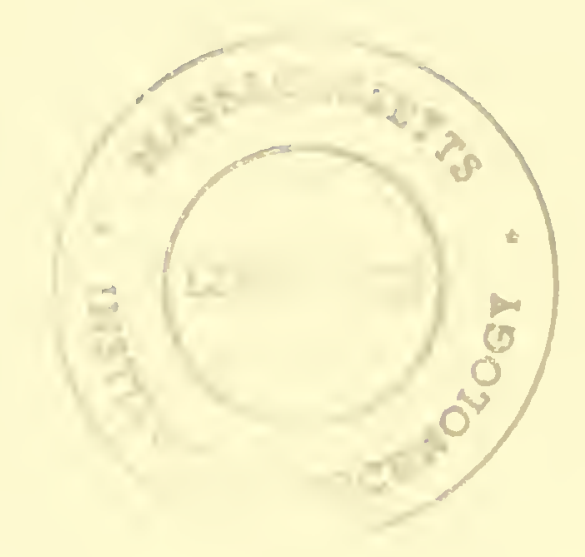




$110.3255^{\circ}$.

91

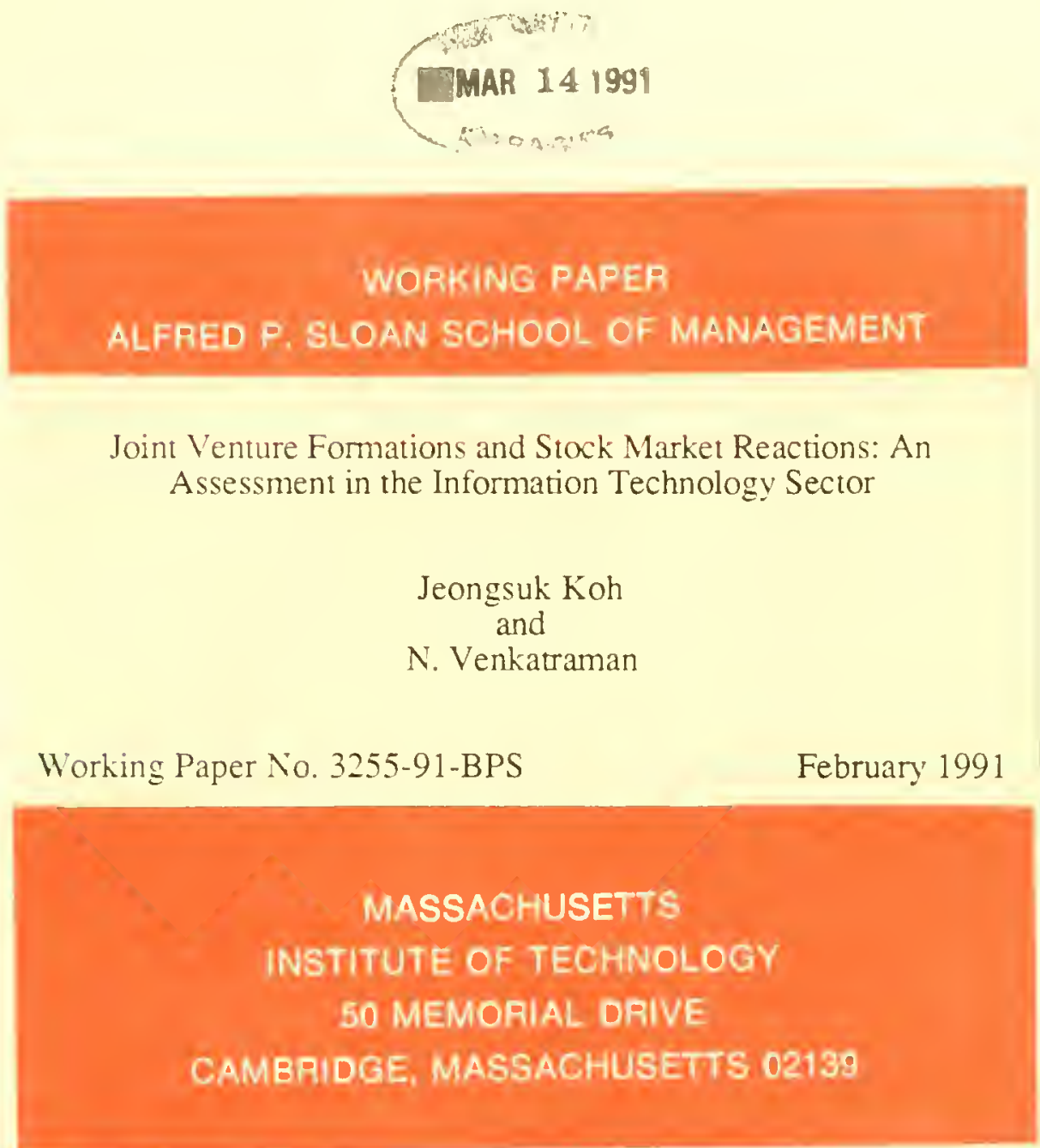



Joint Venture Formations and Stock Market Reactions: An Assessment in the Information Technology Sector

\author{
Jeongsuk Koh \\ and \\ N. Venkatraman
}

Working Paper No. 3255-91-BPS

February 1991 


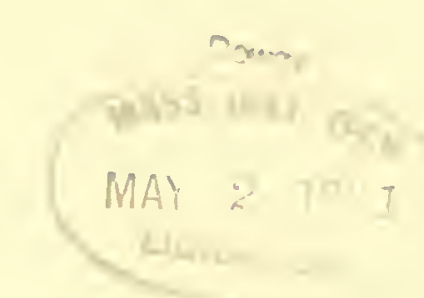




\title{
Joint Venture Formations and Stock Market Reactions: An Assessment in the Information Technology Sector
}

\author{
Jeongsuk Koh \\ McKinsey \& Company \\ 400 South Hope Street \\ Los Angeles, CA 90071-2890 \\ (213)-624-1414 \\ and \\ N. Venkatraman \\ E52-537, Sloan School of Management \\ Massachusetts Institute of Technology \\ Cambridge, MA 02139
}

(617) $253-5044$

February 1991
Academy of Management Joumal
December 1991
(in press)

Acknowledgements. This research was supported by the Management in the 1990s Research Program, and the research consortium on Managing Information Technology in the Next Era (MITNE), at M.I.T. This is a significantly revised version of the paper presented at the Academy of Management Meetings at Washington, August 1989. Harbir Singh's comments and suggestions during this study is acknowledged, without implicating him in any way. We thank the two reviewers for their constructive comments and suggestions on the previous drafts. 



\title{
Joint Venture Formations and Stock Market Reactions: An Assessment in the Information Technology Sector
}

\begin{abstract}
This paper examines the impact of joint venture formation strategies on the market value of the parent firms in the information technology sector using an event-study perspective. In this study, we found that: (a) the announcement of joint venture formation -- on average -- leads to significant increase in the market value of the stocks for the participating parents, (b) an additional, ex-post exploratory calibration indicates the superiority of joint venture formations over three other cooperative mechanisms; and (c) the magnitude and significance of market valuations differ across types of joint venture strategies. Further, an analysis of the impact of joint venture formation announcement (intended JV strategies) and managerial assessments of the contributions of the joint venture to the parents (realized JV strategies) for a subsample indicated a positive and significant relationship. This, while providing preliminary support for the use of stock market referent as one approach to assessing JV performance, highlights the fundamental differences between intended and realized JV strategies. Implications and directions for future research are developed.
\end{abstract}


A central area of research in contemporary strategic management research is concerned with 'hybrid organizational arrangements' (Borys \& Jemison, 1989) at the 'inter-organizational', or the 'network' level (Powell, 1990) involving mechanisms such as joint ventures, technology licensing, cooperative R\&D and marketing arrangements (Mariti \& Smiley, 1983; Harrigan, 1985; Contractor \& Lorange, 1988; Kogut, 1988a). Within this general stream, joint venture is an important mechanism that potentially provides a firm with new and powerful sources of competitive advantage (Harrigan, 1988) and distinctive competencies (Kanter, 1989; Powell, 1990).

Research on joint ventures spans disciplinary boundaries. As represented in Figure 1, we categorize extant research into four types using two dimensions: (a) the dominant theoretical perspective, classified as either the strategic behavior or the transaction cost perspective; and (b) the research focus, namely, whether the focus is on the motives for the formation of joint ventures or on their impacts.

(Insert Figure 1 about here)

The first type of studies -- termed as strategic motives of parents -- seeks to explain the motives for joint venture formations based on a firm's capability to offer distinct products and/or services. These motives primarily relate to enhancement of both market power (Boyle, 1968; Fusfeld, 1958; Mead, 1967; Pate, 1969; Pfeffer and Nowak, (1976a, b) and operating efficiency (Backman, 1965; Berg and Friedman, 1977, 1978; Rockwood, 1983), and Stuckey, 1983). The second type -- termed as impacts of joint ventures -- is concerned with two important questions: (i) what is the impact of joint venture formations? and (ii) what are the conditions when joint ventures have greater impact? Within this type, there is a glaring lack of empirical examination of such questions (notable exceptions are: McConnell and Nantell, 1985; and Harrigan, 1988). 
In contrast, the third type termed as efficient governance mechanisms -- is grounded in the transaction cost perspective (Williamson, 1975) and seeks to explain the motives for forming joint ventures by invoking a logic that this mechanism best minimizes the sum of production and coordination (transaction) costs as compared with other kinds of governance mechanisms (see especially, Balakrishnan \& Koza, 1989; Hennart, 1988; Kogut, 1988a). In other words, these studies explore the rationale and the contexts for the superiority of joint ventures over other mechanisms like vertical integration or long-term contracts. Examples of studies in this type include Shan (1986) and Teece, Pisano, and Russo (1987).

Extending this theoretical perspective into a normative realm, the fourth type -- termed as effectiveness of governance mechanisms -- argues that if firms indeed choose the modes that best minimize production and coordination costs, they are likely to perform better than those that do not adopt the prescribed modes. However, there are no reported empirical studies belonging to this type.

Let us consider the two prominent studies belonging to the second type. McConnell and Nantell (1985) examined 136 joint ventures from a cross-section of industries using an event-study methodology and concluded that joint ventures are, on average, value-creating activities for the parent firms. While they noted that their results are "supportive of the "synergy' hypothesis" (1985: p. 519), they did not further examine the nature of the relationship between differential characteristics (strategies) of JV formations and their impacts. We argue that such an extension would be insightful to understand the factors affecting the variations in valuecreating ability of joint ventures from a strategic management research perspective. Harrigan's (1988) study, in contrast, focused on the JV as the unit of analysis and attempted to isolate the differential effects of joint-venture characteristics. Specifically, she found, using cross-sectional data, that characteristics or strategies -such as partners' and parent-venture relationship traits -- had little impact on joint- 
venture effectiveness, and concluded that industry-level traits are more important determinants of JV success. Given that several authors have argued that the value from JV formations depends upon their characteristics (see for instance, Berg, Duncan, and Friedman, 1982 on the technological, knowledge-acquisition characteristic), the differential role of joint-venture characteristics is an important area of research in strategic management.

Taking these two studies as the point of departure, this paper examines the impact of JV formations on the market value of the parents. More specifically, two objectives underly this study:

(a) an assessment of the impact of JV formations [within one sector of the economy, namely: the information technology sector] on the stock-market valuations for the parents using an 'event-study' methodology; and

(b) a further identification of the differential role, if any, of four strategic factors -- pertaining to the degree of relatedness between the product/market segments of the parents and the joint ventures as well as to areas of partner asymmetry, such as: the degree of relatedness, and relative size -- on the stock market valuations.

A related methodological objective is to explore the nature of the relationship between stock-market reactions to the announcement of joint venture formation (intended JV strategies) and managerial assessments of the role and effects of JV (realized strategies) to provide preliminary support for the use of stock-market returns as one referent in evaluating the role of JV.

\section{THEORETICAL PERSPECTIVES}

\section{Joint Venture as a Value-Creating Mechanism}

Potential Benefits. The range of benefits accruing via joint ventures is extensive, but can be organized into four categories: (a) economies of scale -- through sharing of distinct activities of the parents under one entity (for instance, in 1986 GTE Corp. and United Telecommunications Inc. formed US Sprint, which 
combined the GTE-Sprint long-distance telephone company and GTE Telenet, a data transmission network, with United Telecommunications' US Telecom, a longdistance telephone company, and Data Communications Corp. (Uninet), a United Telecommunications public data transmission network); (b) access to complementary assets -- through pooling of the complementary assets of the partners such as production and marketing and design and manufacturing (for instance, in 1983 AT\&T and Philips formed AT\&T/Philips Telecommunications Systems to manufacture and market AT\&T's network switching equipment, through which AT\&T's technology was linked to Philips' marketing skills); (c) cost or risk sharing -- through joint projects in areas characterized by extremely high development costs coupled with uncertain demand and/or short product- or technology-life cycle (for instance, in 1982 Knight-Ridder and Tele-Communication Inc. formed TKR Cable Co. to acquire, develop, and operate CATV systems); and (d) shaping the scope and basis of competition -- by coopting existing or potential competitors within regulatory constraints (for instance, in 1984 IBM formed Trintex, a videotex-service venture, with CBS and Sears, Roebuck \& Co., which pit IBM against its chief rival AT\&T which had a two-year head start in two-way electronic service field).

Potential Costs. Following Porter and Fuller (1986) we recognize three categories: (a) coordination costs -- due to the need for ongoing coordination between the partners that may be difficult when there are divergent interests between partners (e.g., Moxon \& Geringer, 1985); (b) erosion of competitive position -- when an existing competitor is made more formidable through the transfer of proprietary expertise and market access as well as the lowering entry barriers (e.g., Bresser, 1988); (c) creation of an adverse bargaining position -- this may occur if one partner is able to capture a disproportionate share of the value created by the joint 
venture due to the other partner's adverse bargaining position resulting from specialized and irreversible investments (Balakrishnan \& Koza, 1988).

Rationale for JV Formation. Powell noted that "Firms pursue cooperative agreements in order to gain fast access to new technologies or new markets, to benefit from economies of scale in joint research and/or production, to tap into sources of know-how located outside the boundaries of the firm, and to share the risks for activities that are beyond the scope of the capabilities of a single organization." (1990; p. 315). Such an argument, also consistent with the transaction costs literature, recognizes that a parent will consider forming a joint venture if these potential benefits exceed the corresponding costs associated with forming and operating this inter-organizational arrangement. While each parent considers a specific set of benefits and costs to arrive at its decision, we are concerned with the aggregate assessment by the stock market of intended JV formation strategies. Thus, our approach to the assessment of the intended JV strategies is rooted in the 'event study' model that assesses the impact of an event on a firm's stock prices by estimating the normal (or, expected) return to its stock in the absence of the event (Fama, Fisher, Jensen \& Roll, 1969).

Thus, following Harrigan (1985), Contractor and Lorange (1988), Porter and Fuller (1986) and prior empirical findings presented in McConnell and Nantell (1985), our first hypothesis is:

H1: The abnormal returns associated with the event of joint venture formations are expected to be positive for the participating parents.

We propose and test $\mathrm{H} 1$ in the spirit of an empirical replication of McConnell and Nantell's (1985) findings with a differing time-frame and minimum overlap in the JV sample frame given that most 'law-like findings' in social science research require constructive replication and triangulation across settings. 


\section{Stock Market Reactions to Differential JV Strategies}

A general observation that the formation of JVs has a positive value, by itself, is of limited use for both theory and practice; hence, an important extension is to identify whether differential strategies lead to differential value. For this purpose, we begin from the accumulated evidence in the research stream on diversification and mergers that combinations of resources in a related manner create more value than in an unrelated manner -- popularly termed as the 'relatedness hypothesis' (e.g., Rumelt, 1974; Bettis \& Hall, 1982; Singh \& Montgomery, 1987). The theoretical underpinning is that when a company operates in a set of related businesses, it is possible for the firm to exploit its 'core factor,' leading to economies of scale and scope, efficiency in resource allocation, and opportunity to utilize particular technical and managerial skills (Rumelt, 1982; Chandler, 1990). We extend this set of theoretical arguments to the realm of JV formations (see also McConnell \& Nantell, 1985) to hypothesize that related joint ventures are expected to outperform unrelated ones. Thus, we consider below the role of JVs in (a) influencing product-market segments and (b) the degree of relatedness of the JV with the focal parent's portfolio.

Role of Joint Ventures in Influencing Product/Market Segments. Joint ventures are formed for differing reasons and expectations. In conceptualizing the role of JV in influencing the product--market activity of the parents, we adopt the framework of Salter and Weinhold's (1979) adaptation of Ansoff's (1965) classical framework of corporate strategy. Thus, as shown in Figure 2, the role of JV can be conceptualized along two dimensions: (a) product expansion -- adding new products; and (b) market expansion -- serving new customers. In the identical category, parents and joint ventures are in the same product/market segments; in the related-supplementary (RS) category, the proposed joint ventures provide parents with access to new customers and markets rather than new products; in the 
related-complementary $(\mathrm{RC})$ category, they provide parents with new products rather than access to new markets; and in the unrelated category, parents and joint ventures are in different product/market segments. Figure 2(b) presents illustrative examples of the role classification using this framework.

(Insert Figure 2 About Here)

Each role represents a different type of resource combinations, and, therefore, different opportunities for creating market value (Shelton, 1988). Opportunities for value creation are maximized when the JVs are closely related to their parents in terms of product and/or market scope. Duncan (1982) argued that monopoly gains are most likely when there is overlap in the product-market segments of the parents and joint ventures and Fusfeld (1958) discussed the case of iron and steel firms using JVs to enhance market power through complex channel linkages. In a similar vein, Borys and Jemison (1989) propose that 'hybrid' arrangements that involve pooled interdependence (i.e., a common pool of resources that each partner can draw, as reflected in similar business scopes) are more likely to be successful than those involving sequential interdependence (e.g., supplier or marketing arrangements). Thus, we expect that joint ventures in the identical category (similar products and markets) will create a higher value than those JVs belonging to the RS, RC and unrelated categories.

In contrast, when JVs play no significant role in expanding either products or markets, they are expected to contribute minimally to the market value of the parents. These reflect minimal opportunities of interdependence and sharing of inter-corporate resources, except financial resources. So, we argue that the identical type has the best opportunities and the unrelated type has the worst opportunities. However, the extant theory is weak in distinguishing between the roles of RS and $\mathrm{RC}$ categories. Thus, the hypothesis for differential value based on the patterns of relatedness outlined in Figure 2 is stated as: 
H2: Parents forming joint ventures in the identical category will, on average, report the highest abnormal returns, while parents forming joint ventures in the unrelated category will, on average, report the lowest abnormal returns.

Degree of Relatedness with the Focal Parent's Portfolio. An extension of the considerations of relatedness allows us to examine the division of benefits from the joint-venture formation between parents for the same joint venture. Suppose that parent 1 and parent 2 equally own a joint venture and that, while all of parent 1's product/market segments are related to the specific area of the JV operation, only a small fraction of parent 2 business operation is related to the JV's business. Then, it can be argued that the particular JV provides parent 1 with more opportunities than for parent 2. Specifically, by invoking support from the market power (Pfeffer and Nowak, 1976a, b) as well as operating efficiency arguments (Contractor \& Lorange, 1988; Porter \& Fuller, 1986), the formation of JV provides parent 1 with a greater opportunity to exploit economies of scale and scope in operations than offered to the other parent. Lewis (1990) provides several instances where joint ventures and other collaborative mechanisms have been successfully developed to increase bargaining power, inhibit opponents' moves, as well as raise entry barriers. Consequently, we expect that the same JV is expected to influence the market value of parent 1 greater than parent 2 . This hypothesis formally recognizes the asymmetry that exists in the value derived by the partners based on the differential contributions to the product--market scope of operations.

Thus, the formal hypothesis is as follows:

H3: The parent with the higher sales portion of businesses related to the joint venture's business in an equally-owned joint venture will, on average, report a higher abnormal return than the parent with a lower sales portion.

Related versus Unrelated Partner. The third characteristic is concerned with the degree to which the partners are operating in related businesses. As argued by 
Borys and Jemison (1989) and Harrigan (1988) significant asymmetries between the partners are harmful to venturing performance since their heterogeneity exacerbates differences in how the partners value their joint venture's activities. Further, there is minimal 'common-ground' to develop the process of inter-corporate sharing of skills and capabilities. While we are not generalizing that such ventures should not be attempted, we argue that they are likely to be assessed less favorably by the stockmarket than those joint ventures with a greater overlap of activities and processes. Thus, our premise is that the more 'distant' the partners are in relation to each other, the less opportunities they have for strategic and organizational compatibility ${ }^{1}$. Pfeffer and Nowak (1976a) concluded that horizontal JVs increased their market power, and Duncan (1982) reported a positive, significant impact of related JVs on average rates of returns. Thus:

H4: Firms with related joint venture partners will, on average, report higher abnormal returns than those with unrelated partners.

However, the empirical results for the relatedness hypothesis has been mixed; and Barney (1988) develops specific conditions that enhance the probability of deriving greater value for mergers between strategically related firms. Within the context of joint ventures, Balakrishnan and Koza (1988) employ a transaction cost framework to argue that joint ventures are superior to markets and hierarchies when the costs of valuing complementary assets are nontrivial. They hypothesized that investors will respond less favorably to joint ventures between related partners that are well informed about each other's business since a joint venture may not be a value-maximizing mechanism under conditions in which the costs of valuing and acquiring complementary assets are trivial. The parents' management should have preferred acquisition, and the failure to do so is a signal to the market about either the inefficiency of the management or the managerial motives behind the decision. Thus, it is important to empirically test this hypothesis. 
Large versus Small Partner. An important variable in the choice of joint venture formation pertains to the relative size of the partner. In recent years, incidence of joint ventures in which large and small firms join to create a new entry into the marketplace has been increasing (Hlavacek, Dovey, \& Biondo, 1977; Roberts, 1980) with the small partner firm providing technological resources and the larger partner providing the financial resources. The question is whether the smaller or the larger partner derives more value in these ventures, ceteris paribus. Within the mergers and acquisitions literature, there is a growing body of research on the 'relative size hypothesis.' This provides some evidence that the abnormal return of the acquired firm (small firm) in a merger is larger than that of the acquiring firm (large firm), but the gains in dollar value are approximately equal (Asquith, Bruner, \& Mullins, 1983; Bradley, Desai, \& Kim, 1983). Indeed, Asquith, Bruner, and Mullins (1983) argue that the failure of most studies of mergers to detect any effect of the merger on the acquiring firms is due to the fact that in most cases, the acquiring firms are significantly larger than the acquired firms. Thus, if the dollar value of gain in a merger is divided evenly between the acquiring and acquired firms and if the acquiring firm's market value is 10 times that of the acquired firm, then a 10 percent abnormal return to the shareholders of the acquired firm will translate into an 1 percent abnormal return to those of the acquiring firm (McConnell \& Nantell, 1985).

We argue that it may not be straightforward to apply this argument from the mergers and acquisitions research stream into joint ventures. This is because the small partners may provide resources and capabilities that is proportionately similar to the larger partner in order to derive equal benefits. So, it is unclear whether there will be any greater gain to the smaller partner compared to the larger partner. Obviously, the way in which benefits from the formation of the joint venture are divided between the smaller and larger partners is an important issue in providing 
critical insight into the relevance of the relative size in the selection of partner(s). In the absence of a strong prior theory, we frame our hypothesis in a null form:

H5: The abnormal return of the smaller partner in an equally-owned joint venture will be, on average, no different than that of the larger partner, and the dollar value of their gains will be approximately equal.

\section{Sample Frame}

\section{METHODS}

This study is designed with a focused sample. The specific sector considered for the study is labeled as the 'information technology (IT) sector,' which is growing in importance over the last decade. A broad definition of the I.T. sector has been adopted to include the areas of the economy that directly and/or indirectly deal with products and components -- such as electrical and electronics machinery, equipment, and supplies, measuring instruments and optical goods, communication, computer and data processing as well as electronic imaging and video. The sample includes joint ventures reported in the Wall Strect Journal and referenced in the Wall Street Journal Index over the period between 1972 and 1986. Specifically, in order to be included in the final sample, the common stock returns for at least one of the parents had to be available on the daily returns file of the Center for Research in Security Prices (CRSP) over a period beginning 270 days prior to the announcement of the joint venture. The sample was screened to eliminate parents that made announcements regarding earnings, dividends, mergers, or other important firm-specific information during the arrangement announcement period (which is defined below).

This search and screening procedure yielded a sample of 239 firms involved in 175 joint ventures. Table 1 summarizes the number of joint ventures and the participating parents by the joint venture industry. 


\section{Analytical Methodology}

Model. The primary analytical methodology used to test hypotheses is the standard residual analysis technique based on the market model. The procedure described here follows the methods used by Dodd, Dopuch, and Hollhausen (1984) and Brown and Warner (1985). The day on which the initial article describing a joint venture appeared in the Wall Street Journal was numbered event day $t=0$. The trading days prior to that day were numbered event days $t=-1, t=-2$, and subsequent trading days numbered event days $t=+1, t=+2$, and so on.

Daily market model parameters were estimated for each firm using 200-day returns beginning with event day $t=-270$ and ending with event day $t=-71$.

$$
R_{i t}=a_{i}+b_{i} R_{m t}+u_{i t} t=-270 \text { to } t=-71
$$

where

$R_{i t}=$ common stock return of firm i on day $t$;

$R_{m t}=$ rate of return on the ? RSP value-weighted index on day $t$;

$a_{i}$ and $b_{i}=$ ordinary least squares estimates of market model parameters;

$u_{i t}=$ market model errors.

A firm was included only if it had a minimum of 100 days of returns. The impact of the announcement of the security's price was measured over the two-day trading period consisting of $\mathrm{t}=-1$ and $\mathrm{t}=0$. Henceforth, this two-day trading interval is referred to as the announcement period. The analytical methodology we follow is the same as the conventional approach in prior studies adopting the event-study model. In the interest of space, we have not provided details that are already available in sources such as: Brown and Warner (1985), Lubatkin et. al (1989), McConnell and Nantell (1985) and Friedman and Singh (1989).

Selection of Relevant Time Frame. One of the most important issues in using an event-study is to select the relevant time frame -- daily or monthly returns data with important tradeoffs between the two (see Lubatkin \& Shrieves, 1986 for a discussion relevant to strategic management research). We justify the use of daily 
returns data in this research for the following reasons. First, as McConnell and Nantell (1985) reported $0.73 \%$ of two-day average abnormal return, the magnitude of abnormal returns associated with joint ventures would be significantly small compared to that of abnormal returns associated with events such as mergers. Using monthly data possibly causes the effect of extraneous events to outweigh that of joint ventures. Although the use of daily data may understate abnormal returns associated with joint-venture formation, it, however, makes it possible to capture at least a lower bound estimate that can be attributed directly to joint-venture formation. Second, because in the information technology sector, the major firms tend to form multiple joint ventures, many firms may have to be excluded from the sample, thus reducing sample size and introducing a bias. Third, it is also important to note that this daily-time frame has been adopted by studies of some areas in strategic management in which a corporate action is the outcome of a series of related events or tactics, each of which increases or decreases the probability of the final outcome. Key themes include: mergers and acquisitions (e.g., Chatterjee, 1986; Shelton, 1988; Singh \& Montgomery, 1987) and CEO succession (e.g., Beatty \& Zajac, 1987; Friedman \& Singh, 1989; Lubatkin, Chung, Rogers, \& Owers, 1989).

Statistical Tests. We employ two tests in addition to the conventional t-test to assess the possible impact of outliers. The first is the binomial z-statistic constructed based on the efficient-market assumption that the sign of the parent's abnormal return would follow a binomial distribution, with the probability of its taking a positive sign being 0.5 (Brown \& Warner, 1985). So, if the announcements of joint ventures have no significant effect on the returns to the shareholders of the parents, then the abnormal returns of the parents during the announcement period would be normally distributed. That is, one-half of the parents would have positive abnormal returns and the other half, negative abnormal returns. The other test used was the median signed rank (Wilcoxon) test, which takes into account the 
magnitude as well as the sign of each parent's abnormal return (Hollander \& Wolfe, 1973).

\section{On the Construct Validity of the Dependent Variable Measure}

There exists some concern that the stock market reaction around the date of announcement of an event like the acquisition (or joint ventures) may not reflect the success of implementing the strategy (see for instance, Ravenscraft \& Scherer, 1987; Porter, 1987). In terms of the link between expected performance (initial stock market reaction) and the long-term actual performance of acquisitions (realized strategies), some preliminary support has recently been forthcoming in the mergers and acquisitions stream (e.g., Healy, Palepu, and Ruback, 1990), where it is relatively easy to adopt accounting data to make meaningful comparisons. In contrast, in the case of joint ventures, it is difficult to use publically available aggregate data to delineate the portion attributable to a particular joint venture sources, requiring us to resort to primary data collection.

Thus, we test for the convergent validity between the measures of stock market reaction and managerial assessments. For managerial assessments, we attempted to obtain the name and address of the CEO for every firm in our sample (parents). Letters were sent to the CEOs with a two-page questionnaire describing the purpose of the study and a request to forward it to the manager most knowledgeable about the status and benefits of each of the joint ventures. Several companies (especially those who entered into the joint venture in the 1970s) had terminated the JV operations and could not identify knowledgeable informants to provide the required data. We received usable data on managerial assessments of the JV performance from 56 parents (representing nearly $25 \%$ of the study sample). It is important to recognize that the sample is biased in favor of those joint ventures formed in the $1980 \mathrm{~s}^{2}$. Each manager was requested to provide assessments 
pertaining to the IV in relation to five key objectives using a scale $5=$ much better than expectations to $1=$ much worse than expectations. The five indicators were: (i) contributions to sales; (ii) profitability; (iii) technological expertise; (iv) marketing capabilities; and (v) sharing of financial risks. These indicators are consistent with Mariti and Smiley (1983) Harrigan (1985), and Contractor and Lorange (1988). A summated index was calculated since these indicators covary consistently as indicated by Cronbach $\alpha=0.71$.

The association between abnormal returns (market) and management assessment is estimated using two different statistics: a parametric Pearson correlation coefficient and a non-parametric Mann-Whitney test to ensure robustness of results under differing distributional assumptions. The correlation coefficient was $r=0.389(p<.01)$ and the Mann-Whitney coefficient was $W=286$; $p<.01^{3}$. These statistics provide support for the construct validity (especially, convergent validity of the measures) of the market-based measurement scheme. A very high coefficient of association should not be expected given that this approach does not formally recognize the process underlying the realization of benefits from this form of intercorporate arrangement (see for instance, Jemison \& Sitkin, 1986). The upperbound for such a correlation coefficient is much less than one (although we cannot theoretically specify it), and we believe that these results provide preliminary, but consistent support for the validity of stock market reaction as a valid referent for assessing significant strategic events.

\section{RESULTS}

\section{H1: Stock-market Reaction to JV Formations}

Table 2 presents the estimated abnormal returns associated with joint ventures and the test statistics. The two-day announcement-period average abnormal return is 0.87 percent and all three tests indicate that the null hypothesis can be rejected at the 0.01 level of significance. In addition, we divided the sample into manufacturing 
and non-manufacturing sector (see Table 1) to test the stability of the results, and found that the results were not statistically different between the two subsamples.

Further, the two-day announcement-period abnormal return for each firm was multiplied by the security's total market value as of event day $t=-3$. The crosssectional average of the dollar values is $\$ 12.6$ million. It is useful to note that the unexpected average change in wealth from joint ventures is greater than the total market value of the equity of a significant fraction of all companies listed on the NYSE and ASE. While this does not reflect the total value created by joint venture formation, it is a lower-bound estimate of the value of joint-venture formation. Further, the average value of managerial assessment for the subsample available to test this hypothesis is 3.99 (standard deviation: 0.22), which is statistically different $(p<.01)$ from the mid-point of the 5-point Liket scale, lending further support for this hypothesis.

\section{Exploratory Comparison of Stock Market Reactions to Alternate Cooperative} Mechanisms. An important premise underlying this study is that the stock market reactions to JV formations, on average, will be significantly different from zero. A rival hypothesis is whether other cooperative arrangements would also be perceived significantly by the stock market. To test this rival hypothesis, we assessed whether other cooperative mechanisms were differentially perceived by the stock market. Specifically, we considered mechanisms, such as technology exchange, licensing, marketing, and supply agreements. This analysis is exploratory given the infancy of theoretical and empirical work in this stream, where their relative attractiveness cannot be theoretically distinguished. Indeed, in a recent article, Powell (1990) observed that "There is no clear cut relationship between the legal form of cooperative relationships and the purposes they are intended to achieve. The form of the agreement appears to be individually tailored to the needs of the respective parties, and to tax and regulatory considerations." (1990; p. 313). Hence, 
our interest is to assess whether there is any discernable pattern in the degree of market reactions to the different mechanisms.

For this analysis, we adopted the same search-and-screening procedure as in the case of joint ventures. This process yielded a sample of 102 firms in 76 technology exchange agreements, 60 firms in 45 licensing arrangements, 91 firms in 77 marketing agreements, and 50 firms in 38 supply agreements. Estimated average abnormal returns associated with these four types of cooperative arrangements are also presented in Table 2. The average abnormal return during the announcement period for technology exchange agreements is 0.8 percent, $(p<0.01)$, which confirms the importance of technology access as a motive for cooperation in this sector. Since the binomial z-statistic and the Wilcoxon test do not reject the null hypothesis, even this result could be due to a few outlier observations. Further, all three tests indicate that the other three mechanisms are not perceived significantly by the stock market.

However, we could not normalize the values for these mechanisms using any common basis since technology exchange agreements might involve complex barter or technology access, marketing agreements might involve complex non-linear, graded percentage of sale fee structures, licensing and royalties might involve future options. etc. Hence, our observations are: (a) JVs and technology license arrangements are viewed significantly positively (i.e., different from zero); and (b) the other three arrangements are not viewed significantly by the market.

(Insert Table 2 about here)

\section{H2: Roles of Joint Ventures}

Two dimensions -- 'adding new products' and 'serving new customers' -- are employed to develop a classificatory scheme for the roles of joint ventures shown in Figure 2. The product dimension is used to distinguish between truly new products and those similar to existing products of the parent(s) based on whether parents or divisions involved in joint-venture formation already had operations in the 


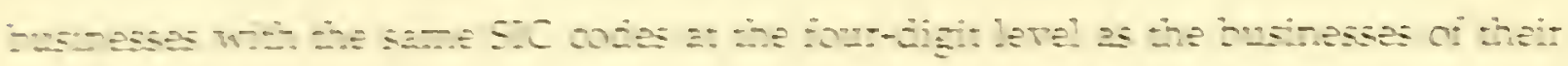

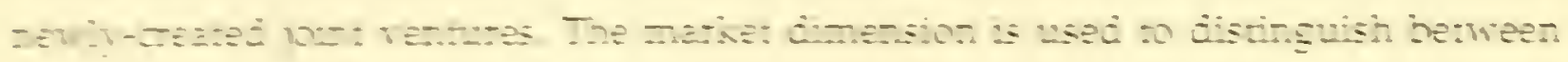

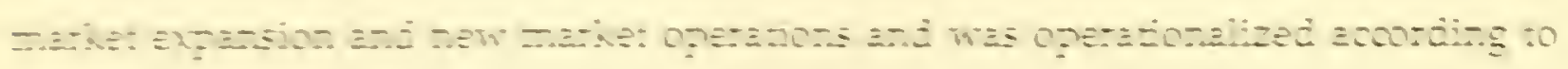
w-ว

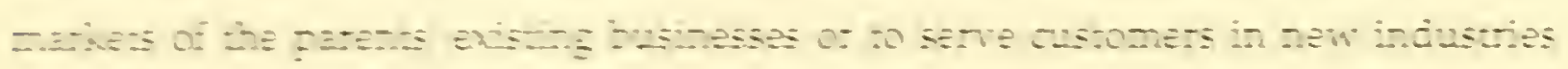

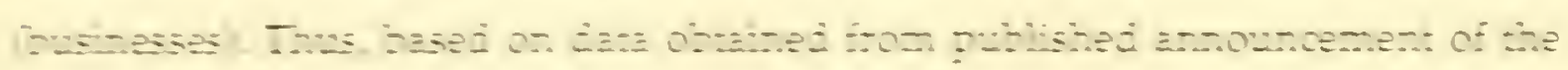

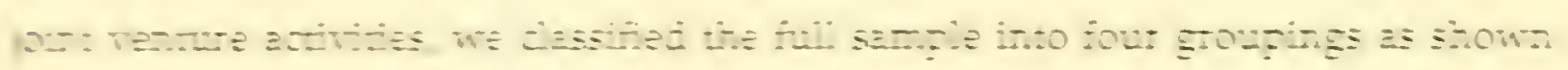

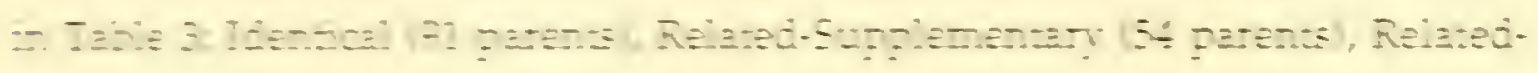

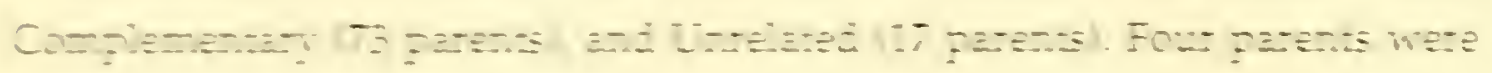

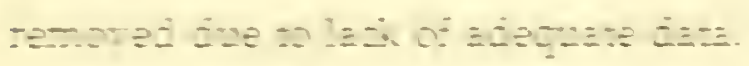

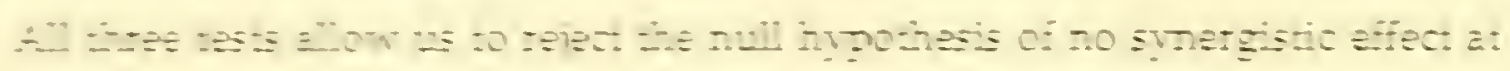

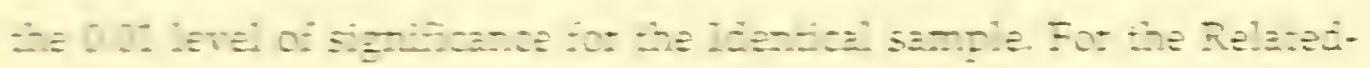

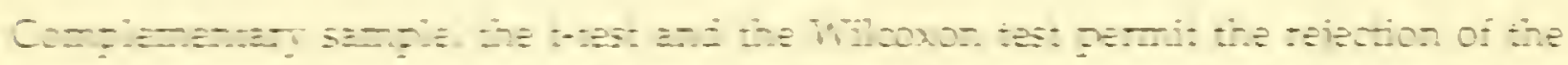

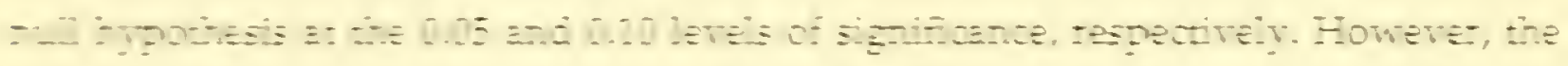

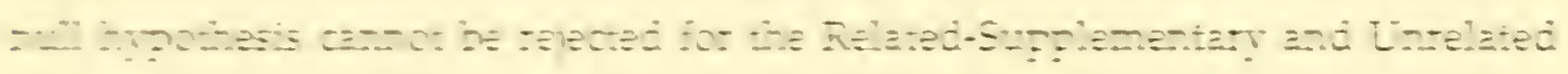

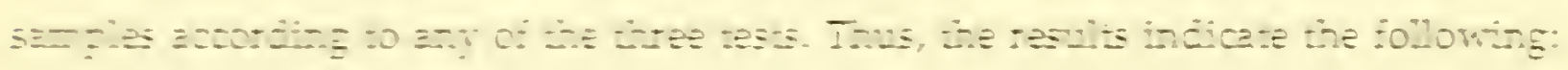

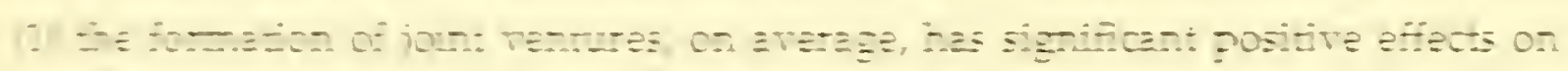

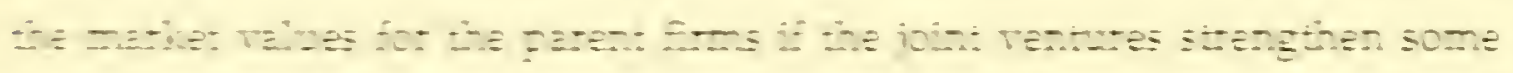

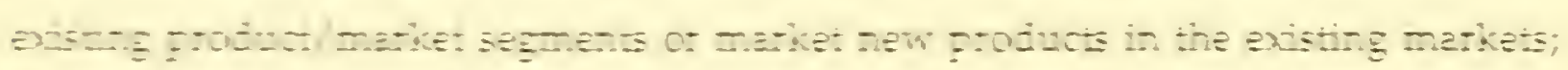

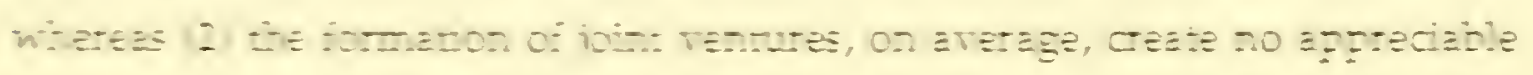

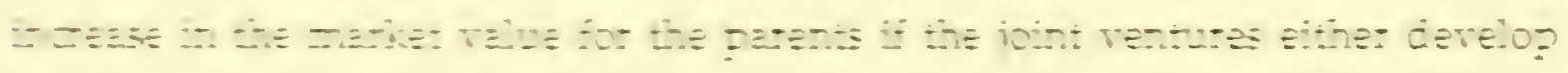

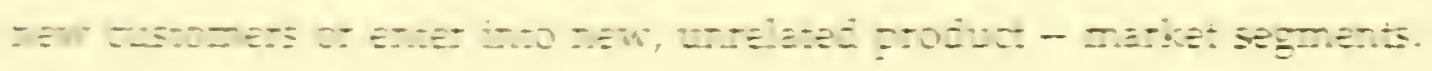

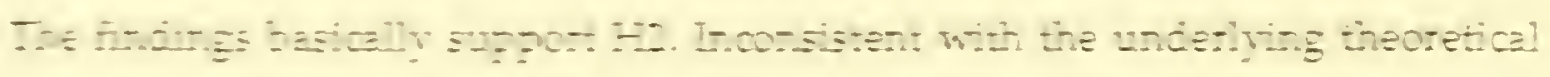

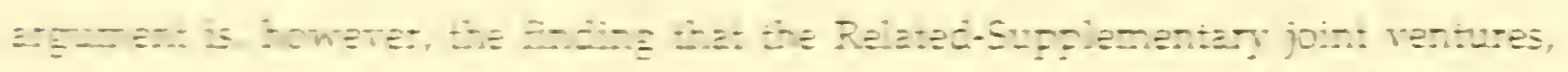

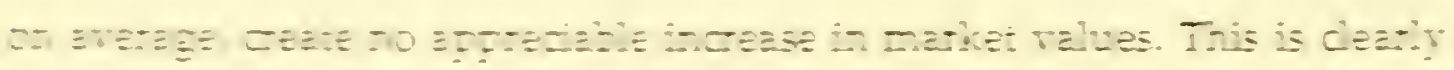
cor

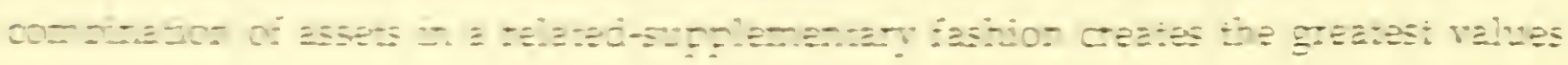




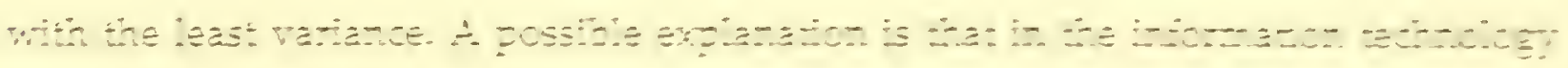

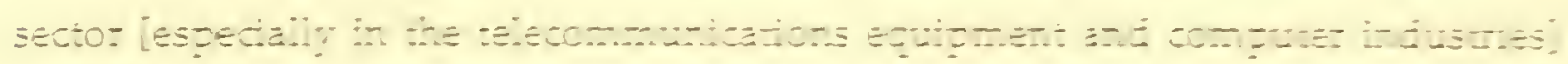

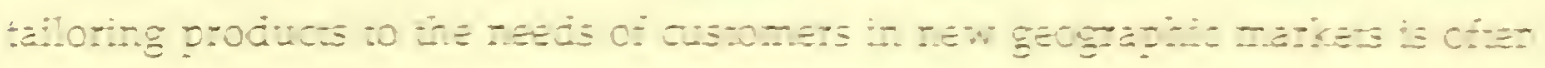

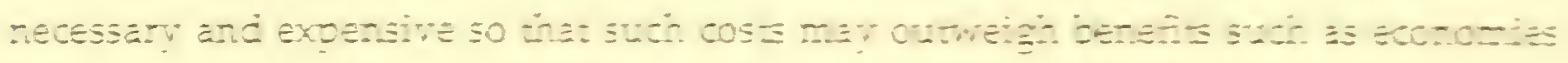

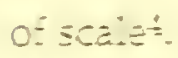

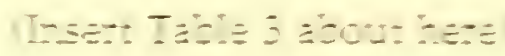

H3: Degree of Relatedness with the Focal Parents Portiolio

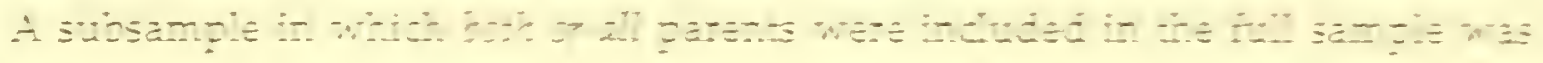
¿

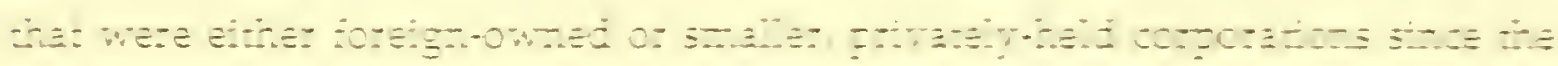

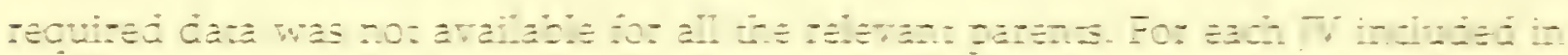

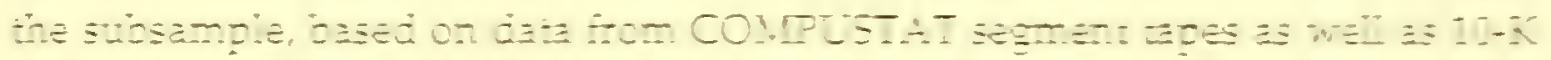

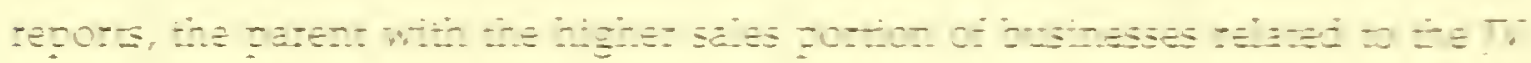

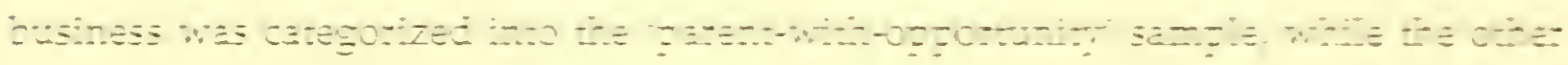

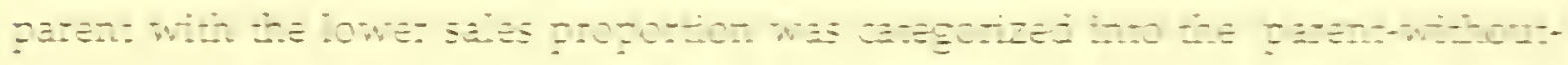

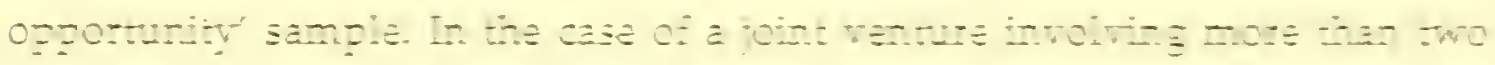

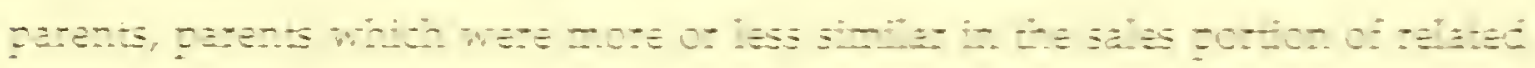

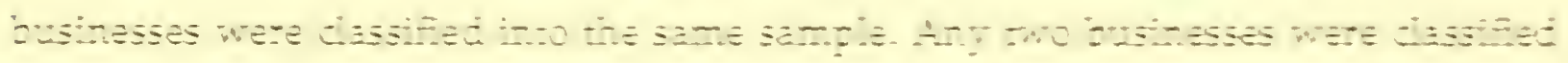

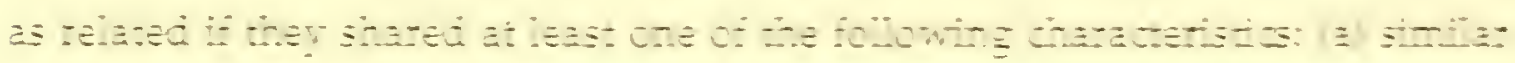

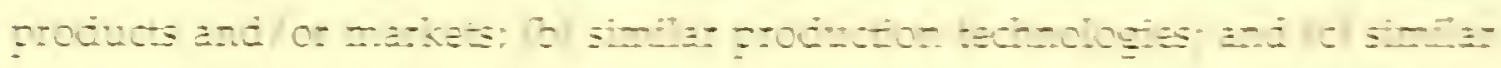

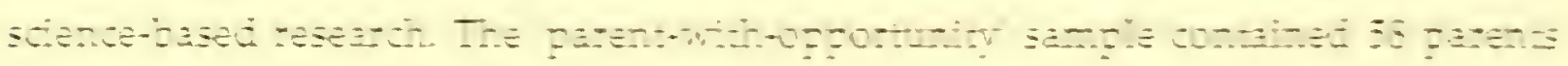

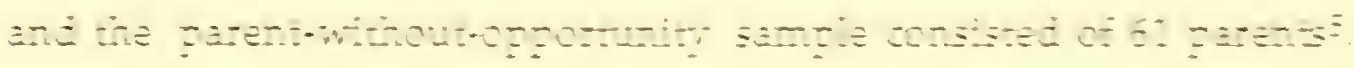

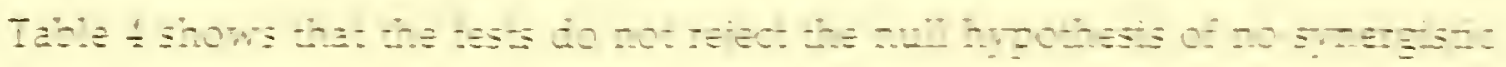

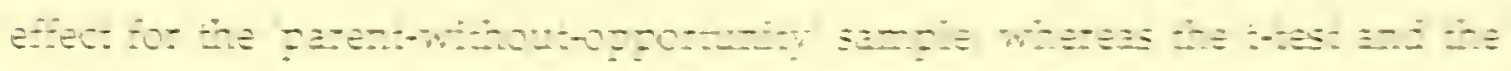

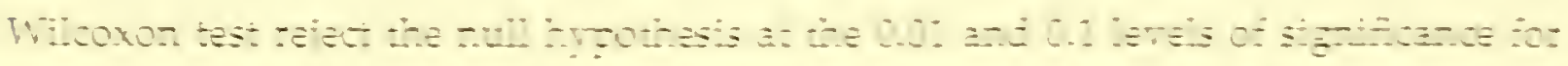

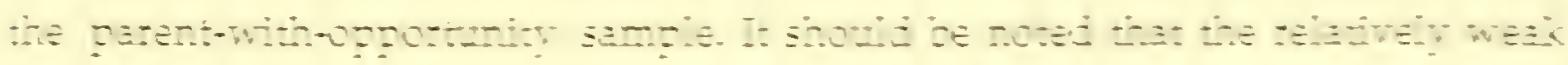

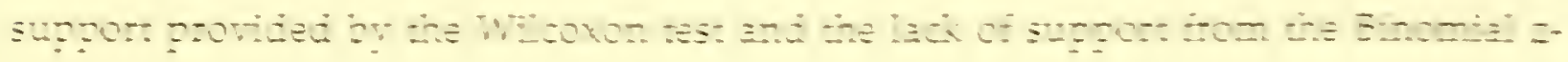


test stems from the peculiar distribution of the data as shown by the corresponding significance levels associated with the binomial z-statistic and the Wilcoxon test for the full paired sample. Nevertheless, the results support the hypothesis that the parent with more businesses related to the joint venture's business derives more benefits from the joint venture than the other parent(s).

(Insert Table 4 about here)

\section{H4: Related versus Unrelated Partner}

Parents were categorized into the 'related-partner' sample if they had partners with operations in related businesses. Thus, the 'unrelated-partner' sample consisted of parents with partners which had operations in unrelated businesses. Relatedness was operationalized as in the test of H3. In the case of joint ventures involving multiple partners, parents with at least one related partner were catergorized into the 'related-partner' sample. Again, due to inadequate information, three parents were excluded. The 'related-partner' sample consisted of 183 parents, while the 'unrelated-partner' sample had 53 parents.

As shown in Table 5, all three tests reject the null hypothesis of no significant impact at the 0.01 level of significance for the 'related-partner' sample, whereas no test rejects the null hypothesis for the 'unrelated-partner' sample. This finding provides strong support for $\mathrm{H} 4$, as it appears that joint ventures involving related partners are more effective for the parents than otherwise. This finding is at odds with Balakrishnan and Koza's (1988) competing hypothesis, and thus is an important area for further inquiry.

(Insert Table 5 about here)

\section{H5: Large versus Small Partner}

A subsample of joint ventures in which both or all parent firms were included in the full sample was identified. For each joint venture included in the subsample, the parent with the larger market value of its common stock three trading days 
before the announcement of the JV formation was categorized into the 'largepartner' sample, while the other parent with the smaller market value was categorized into the 'smaller-partner' sample. In the case of a joint venture involving more than two parents, parents which were more or less similar in size were categorized into the same sample. The 'large-partner' sample contained 59 parents and the 'small-partner' sample contained 60 parents. The remaining 120 parents in the full sample were placed into the 'all-other' sample. This third sample contained parents for which the partner's common stock was not listed on either the NYSE or ASE during the period of the study.

Table 6 shows that the shareholders of the smaller partner earned significantly positive abnormal return, while those of the larger partner earned insignificant abnormal return. This result is not consistent with McConnell and Nantell's (1985) finding that shareholders appear to gain when firms enter into joint ventures regardless of the relative size of their partner. Moreover, the result that smaller partners, on average, earn higher gains in dollar value (\$19.2 million) than larger partners ( $\$ 2.3$ million) is not consistent with the 'relative size hypothesis' of the merger studies. It may be argued that having a larger firm as a joint venture partner will be more beneficial.

The stock market perceives that a small firm with a large firm as the jointventure partner could derive significant benefits such as the spillover of the large partner's reputation to the small firm. For example: the large firm's endorsement of the small firm as a partner may be a valuable asset. On the other hand, the asymmetry in size is likely to lead the smaller partner into an adverse bargaining position. Indeed, the overall control over major decisions in the joint venture may be at the large partner's mercy.

(Insert Table 6 about here) 


\section{DISCUSSIONS}

Impact of Joint Venture Formations on the Market Value

"Does the stock market react positively to joint venture formations?" -- We set out to address this question under ceteris paribus conditions based on a prior research that the formation of joint ventures (McConnell \& Nantell, 1985; see also Woolridge and Snow, 1990) will have a positive and significant impact on the market value of the participating firms. Our results are consistent with our expectations, thus providing an independent empirical corroboration to an important theoretical axiom using a focused sample frame and a more recent time period. Further, our exploratory calibration of the relative valuations of different inter-corporate cooperative mechanisms revealed that joint ventures and technology exchange are viewed positively relative to other mechanisms. This is consistent with the general expectation that within the I.T. sector, a significant area of business competence is technology. This exploratory result pertaining to different cooperative mechanisms, however, begs for a more systematic theorizing to distinguish among the differential avenues for creating value along a contingency framework.

\section{Differential Values of Joint Venture Strategies}

"Does the stock market differentially value the different joint venture strategies?" -- We next examined a set of strategies that could lead to differential valuation and demonstrated that the magnitude and significance of value creation from joint ventures varied across different types of joint ventures and different types of partners (H2 through H5). Harrigan's $(1985,1988)$ findings are derived from multiple sectors, but we focused on one sector, thereby mitigating industry effects in isolating the differential effects of joint venture strategies. We demonstrated that stock market reacts differentially to the strategies adopted to form joint venture under differing conditions. 
Specifically, we found that the parents forming JVs in the identical and relatedcomplementary categories reported higher gains in abnormal returns than those parents forming other types of JVs; the parents with a higher proportion of business operations with the JV operations earned higher abnormal returns than other parents; the parents with related partners received a greater increase in the value than those with unrelated partners; and finally the smaller partner benefitted more from JV formation than the larger partner.

If we juxtapose the results relating to joint ventures with those of technology exchange and marketing agreements, we highlight the importance of technologybased competence in this sector. Because of rapid technological changes and consequent competitive pressure, firms form the Identical-type joint ventures to acquire complementary technologies and strengthening their product/market scope (as described for the CDC-NCR venture). We develop a sector-specific conjecture that access to complementary technologies contributes significantly to value creation as shown by the significantly positive abnormal returns for the Identical-type joint ventures and technology agreements. Further, Our results are consistent with those of Mariti and Smiley (1983) involving seventy cooperative agreements in Europe and is in general agreement with the knowledge-acquisition aspect of joint ventures (Berg \& Friedman, 1980; Powell, 1990).

In contrast, market access, another important motive for forming cooperative arrangements, does not appear to be viewed significantly by the stock market as indicated by the lack of expected findings associated with the Related-Supplementary joint ventures and marketing agreements. These findings are at odds with their strategic significance and popularity, especially with the conventional wisdom that new marketing and distribution channels are essential for supporting the creation of new products and intensifying globalization. Although a partial explanation can be found in the specifics of the sample studies, a useful line of inquiry would be to 
Lereion a more carefu? an alysis of rarious types of cooperative arangements to

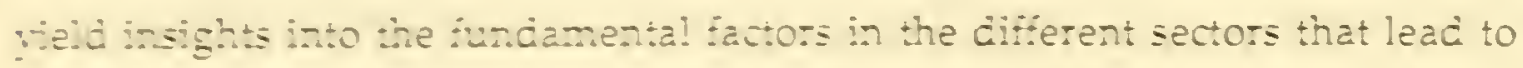
incejsed valuation c: Il 'omations by the market.

\section{Extensions}

Neea for a Contingert Research Framework. A useful line of inquiry would be :o develop a framework that recognizes, at minimum, the following four issues: (a) ine iriustry and marbestrature jabors that delineate the key characteristics for oming join ver.tures as well as othe: forms o cooperative arrangements; (b) the

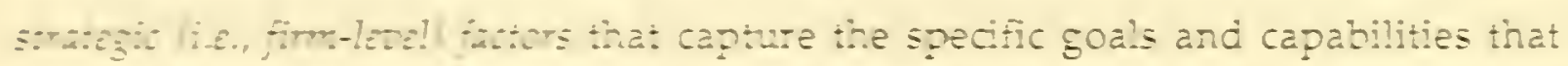
could inform on the approntiateness of the difierent arrangements; (c) the lecel of aratys: (i.e., parent o: the J) comesponding to the difierent theoretical and metrodological recuirements; and (d) the toming co assessing the impact of JV (exand versus ex-pos:). Such a hamework could serve to organize the research cutetions as well as zynthesizing the emerging results.

Delireating the Process of Derising Value from Joint Ventures. There is considerable value in focusing on the process of talue-creation sia cooperabite arargamar.: For example, our research relied on the collective ability of the stock market to grocess the recuired information to assess the impact of JV (intended) strategies. This should be complemented by a process theory that reconciles the important differences between intended and realized IV stategies. Such an attempt cou'd build from Jemison's (1959) discussions on the piocess of deriving value from accuisitions and acopt a goa'-centered approach to organizational effectiveness Cameron \& ihetten, iss3). Such an extension will go a long way in developing a much-needed integration between market-besed assessments (relying on financial theoyl and a lasge: conceptualizations o: organizational effectiveness. 


\section{REFEREYCES}

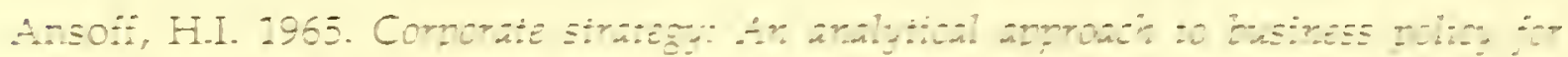

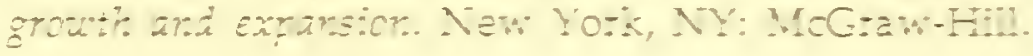

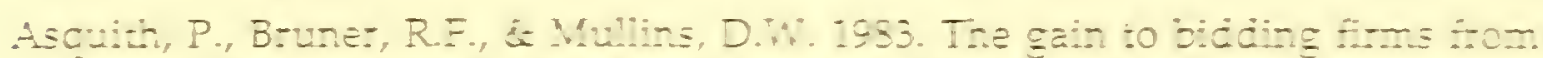

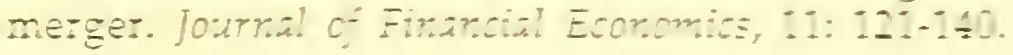

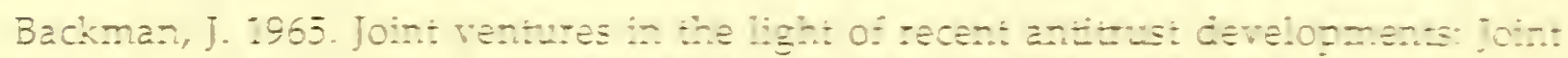

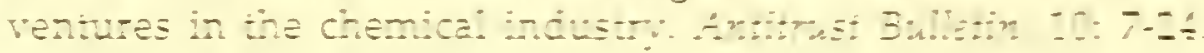

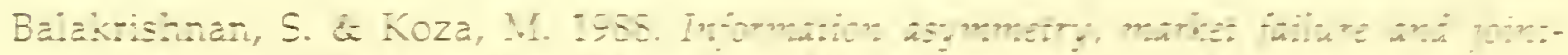

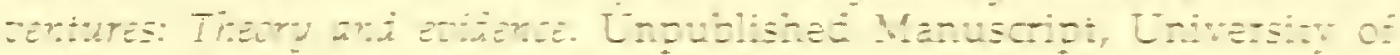

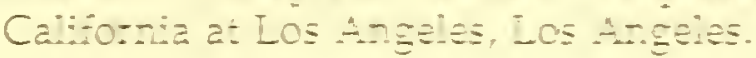

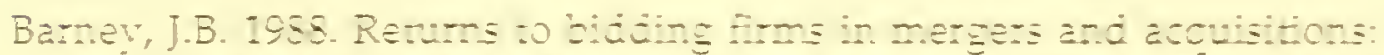

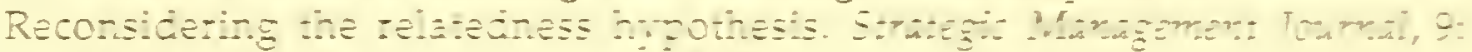

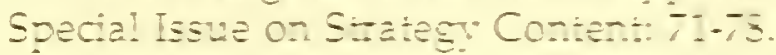

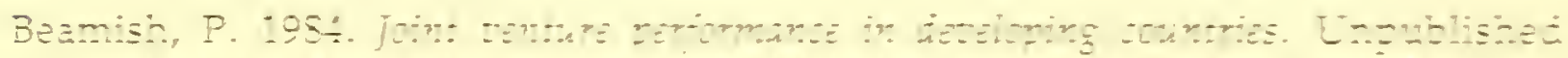

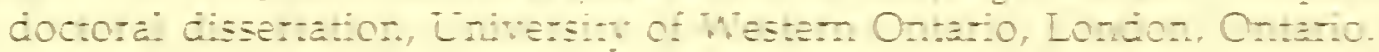

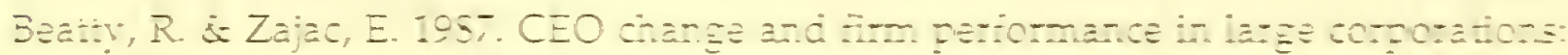

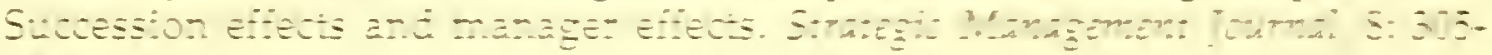
$3 \%$

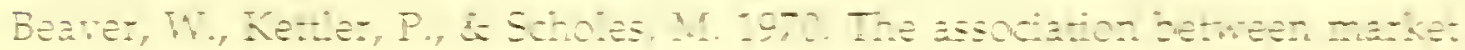

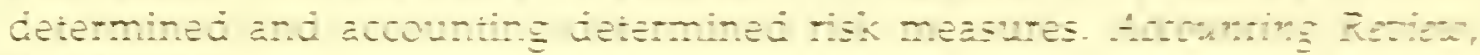
$\div 5: 6 \div-652$

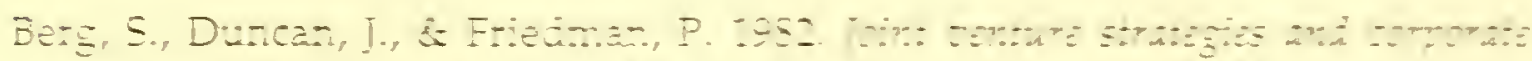

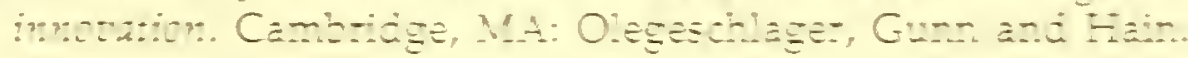

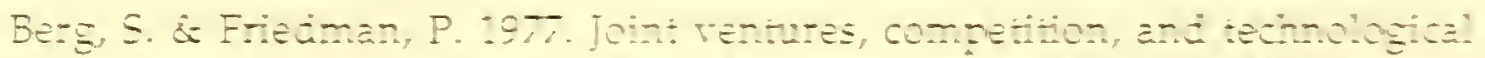

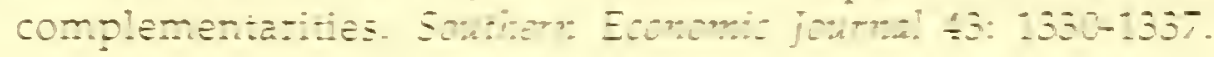

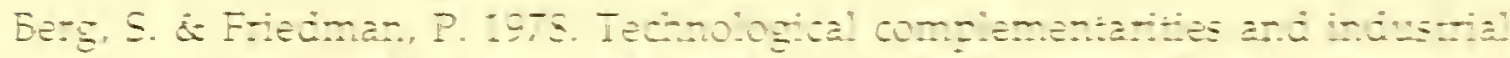

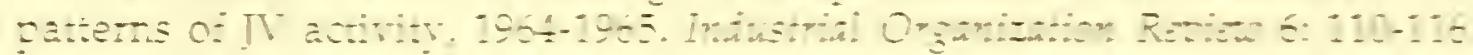

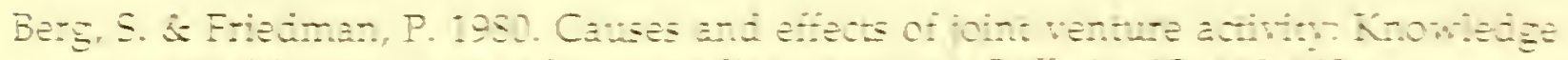

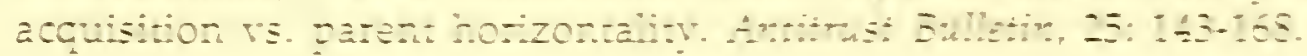

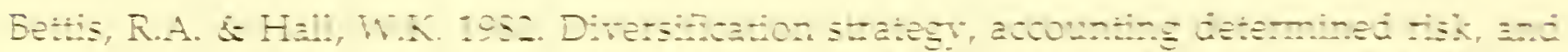

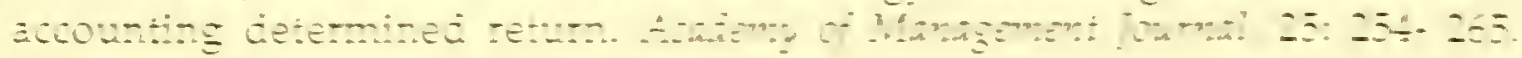


Boyle, S.E. 1968. An estimate of the number and size distribution of domestic joint subsidiaries. Antitrust Law and Economics Review, 1: 81-92.

Borys, B. \& Jemison, D.B. 1989. Hybrid arrangements as strategic alliances:

Theoretical issues and organizational combinations. Academy of Management Review, 14: 234-249.

Bradley, M., Desai, A., \& Kim, E.H. 1983. Specialized resources and competition in the market for corporate control. Working Paper, University of Michigan.

Bresser, R. 1988. Matching collective and competitive strategies. Strategic Management Journal, 9: 375-385.

Brown, S.J. \& Warner, J.B. 1985. Using daily returns: The case of event studies. Journal of Financial Economics, 14: 3-31.

Cameron, K., \& Whetten, D.A. 1983. Some conclusions about organizational effectiveness. In K.S. Cameron \& D.A. Whetten (Eds.), Organizational Effectiveness: A Comparison of Multiple Methods, New York, NY: Academic Press. 261-277.

Chatterjee, S. 1986. Types of synergies and economic value: The impact of acquisitions on merging and rival firms. Strategic Management Journal, 7: 119-139.

Contractor, F.J. \& Lorange, P. 1988. Cooperative strategies in international business. In F.J. Contractor \& P. Lorange (Eds.), Cooperative Strategies in International Business, Lexington, MA: Lexington Books.

Dodd, P., Dopuch, P., \& Hollhausen, R. 1984. Qualified audit opinions and stock prices. Journal of Accounting and Economics, 6: 3-38.

Duncan, J.L. 1982. Impacts of new entry and horizontal joint ventures on industrial rates of return. Review of Economics and Statistics, 64: 339-342.

Fama, E.F., Fisher, L., Jensen, M.C., \& Roll, R. 1969. The adjustment of stock prices to new information. International Economic Review, 1: 1-21.

Friedman, S. \& Singh, H. 1989. CEO succession and stockholder reaction: The influence of organizational context and event context.. Academy of Management Journal, 32: 718-744.

Fusfeld, D., 1958. Joint subsidiaries in the iron and steel industry. American Economic Review, 48: 578-587.

Harrigan, K.R., 1985. Strategies for joint ventures. Lexington, MA: Lexington Books. 
Harrigan, K.R., 1988. Strategic alliances and partner asymmetries.in international business. In F.J. Contractor \& P. Lorange (eds.), Cooperative strategies in international business, Lexington, MA: Lexington Books.

Healy, P., Palepu, K., \& Ruback, R. 1990. Does corporate performance improve after mergers? Working Paper 3149-90, MIT Sloan School of Management.

Hennart, J.F., 1988. A transaction cost theory of equity joint ventures. Strategic Management Journal, 9: 361-374.

Hlavacek,J.D., Dovey, B.H., \& Biondo, J.J. 1977. Tie small business technology to marketing power. Harvard Business Review, 55: 106-116.

Hollander, M. \& Wolfe, D.A. 1973. Nomparametric statistical methods. New York, NY: Wiley.

Jemison, D. \& Sitkin, S. 1986. Corporate acquisitions: A process perspective. Academy of Management Review, 11: 145-163.

Jensen, M.J. \& Ruback, R. 1983. The market for corporate control: The scientific evidence. Journal of Financial Economics, 11: 5-50.

Kanter, R.M. 1989. When giants learn to dance. New York, NY: Simon \& Schuster.

Kogut, B., 1988a. Joint ventures: Theoretical and empirical perspectives. Strategic Management Journal, 9: 319-332.

Kogut, B., 1988b. A study of the life cycle of joint ventures. In F.J. Contractor \& P. Lorange (eds.), Cooperative strategies in international business, Lexington, MA: Lexington Books.

Lewis, Jordan. 1990. Partnerships for profit. New York, NY: Free Press.

Lubatkin, M., Chung, K., Rogers, R., \& Owers, J. 1989. Stockholder reactions to CEO changes in large corporations. Academy of Management Journal, 32: 47-68.

Lubatkin, M. \& Shrieves, R. 1986. Towards reconciliation of market performance measures to strategic management research. Academy of Management Review, 11: 497-512.

Mariti, P. \& Smiley, R.H. 1983. Co-operative agreements and the organization of industry. Journal of Industrial Economics, 31: 437-451.

McConnell, J. \& Nantell, J. 1985. Common stock returns and corporate combinations: The case of joint ventures. Journal of Finance, 40: 519-536. 
Mead, W.J. 1967. Competitive significance of joint ventures. Antitrust Bulletin, 12: 819-851.

Moxon, R.W. \& Geringer, J.M. 1985. Multinational ventures in the commercial aircraft industry. Columbia Journal of World Business, 55-62.

Pate, J.L. 1969. Joint venture activity, 1960-1968. Economic Review, Federal Reserve Bank of Cleveland, 16-23.

Pfeffer J. \& Nowak, P. 1976a. Joint ventures and interorganizational interdependence. Administrative Science Quarterly, 21: 398-418.

Pfeffer, J. \& Nowak, P. 1976b. Pattern of joint venture activity: Implications for antitrust research. Antitrust Bulletin, 21: 315-339.

Porter, M. 1980. Compctitive strategy. New York: Free Press.

Porter, M. 1987. From competitive strategy to competitive advantage. Harvard Business Review, May-June: 43-59.

Porter, M. \& Fuller, M. 1986. Coalitions and global strategy. In M. Porter (ed.), Competition in global industries. Boston: Harvard Business School Press.

Powell, W. 1990. Neither market nor hierarchy: Network forms of organization. In B. Staw \& L. L. Cummings (Eds.) Research in Organizational Behavior, 12: 295-336. Greenwich, CT: JAI Press.

Ravenscraft, D.J., \& Scherer, F.M. 1987. Mergers, sell-offs and economic efficiency. Brookings Institution, Washington, DC.

Roberts, E.B. 1980. New ventures for corporate growth. Harvard Business Rcview, July-August: 134-142.

Rockwood, A. 1983. The impact of joint ventures on the market for OCS oil and gas leases. Journal of Industrial Economics, 31: 452-468.

Rumelt, R.P.1982. Diversification strategy and profitability. Strategic Management Journal, 3: 359-369.

Salter, M.S. \& Weinhold, W.A. 1979. Diversification through acquisition: Strategies for creating economic valuc. New York: Free Press.

Shan, W. 1986. Technological change and strategic cooperation: Evidence from commercialization of biotechnology. Unpublished doctoral dissertation, University of California, Berkeley. 
Shelton, L.M. 1988. Strategic business fits and corporate acquisition: Empirical evidence. Strategic Management Journal, 9: 279-287.

Singh H. \& Montgomery, C.A. 1987. Corporate acquisition strategies and economic performance. Strategic Management Journal, 8: 377-386.

Stuckey, A.1983. Vertical integration and joint ventures in aluminum industry. Cambridge, MA: Harvard University Press.

Teece, D., Pisano, G., \& Russo, M. 1987. Joint ventures and collaborative arrangements in the telecommunications equipment industry. International Business Working Paper No. IB-9, U.C. at Berkeley.

Williamson, O.E. 1975. Markets and hicrarchies: Analysis and antitrust implications. New York: Free Press.

Woolridge, J.R., \& Snow, C.C. Stock market reaction to strategic investment decisions. Strategic Management Journal, 11: 353-364. 
TABLE 1

Number of Joint Ventures and Parents by Joint Venture Industry

\begin{tabular}{|l|c|c|}
\hline Joint Venture Industry & Joint Ventures & Parents \\
\hline Manufacturing Sector & & \\
Electronic Components & 19 & 20 \\
Electronic Equipment & 8 & 8 \\
Precision Controls & 11 & 11 \\
Computer \& Peripherals & 31 & 42 \\
Tape \& Disc & 6 & 8 \\
Photo \& Office Equip. & 7 & 10 \\
Comm. Equipment & 20 & 23 \\
\multicolumn{1}{|c|}{ Subtotal } & 102 & 122 \\
\hline \hline Nonmanufacturing & & \\
Sector & & 23 \\
Motion Pictures & 15 & 23 \\
Cable Services & 21 & 41 \\
Comm. Services & 26 & 117 \\
Software \& Data Process & 11 & \\
Sub-total & 73 & $\mathbf{2 3 9}$ \\
\hline \multicolumn{1}{|c|}{ Total } & & \\
\hline
\end{tabular}


TABLE 2

Stock Market Reaction to the Formations of Joint Ventures and Other Cooperative Arrangements

\begin{tabular}{|c|c|c|c|}
\hline $\begin{array}{r}\text { Type } \\
\text { (\# of Firms) }\end{array}$ & $\begin{array}{c}\text { Mean AR } \\
\text { (t-stat.)a }\end{array}$ & $\begin{array}{c}\text { Positive ARs } \\
\text { (B-stat.)b }\end{array}$ & $\begin{array}{l}\text { Wilcoxon } \\
\text { (z-stat.)c }\end{array}$ \\
\hline $\begin{array}{l}\text { Joint } \\
\text { Ventures } \\
(N=239)\end{array}$ & $\begin{array}{l}0.87 \% \\
(5.28)^{* *}\end{array}$ & $\begin{array}{c}58 \% \\
(2.52)^{* *}\end{array}$ & $(3.30)^{* *}$ \\
\hline $\begin{array}{l}\text { Technology } \\
\text { Exchange } \\
\left(N^{\top}=102\right)\end{array}$ & $\begin{array}{c}0.80 \\
(2.66)^{* *}\end{array}$ & $\begin{array}{c}57 \\
(1.39)\end{array}$ & (1.67) \\
\hline $\begin{array}{l}\text { Licensing } \\
\text { Agreements } \\
(N=60)\end{array}$ & $\begin{array}{c}0.40 \\
(0.95)\end{array}$ & $\begin{array}{c}48 \\
(-0.26)\end{array}$ & $(-0.33)$ \\
\hline $\begin{array}{l}\text { Marketing } \\
\text { Agreements } \\
\left(N^{\top}=91\right)\end{array}$ & $\begin{array}{c}0.01 \\
(0.04)\end{array}$ & $\begin{array}{c}37 \\
(-2.41)^{* *}\end{array}$ & $(-3.21)^{* *}$ \\
\hline $\begin{array}{l}\text { Supply } \\
\text { Agreements } \\
\left(N^{\top}=50\right)\end{array}$ & $\begin{array}{c}-0.13 \\
(-0.27)\end{array}$ & $\begin{array}{c}46 \\
(-0.57)\end{array}$ & $(-0.18)$ \\
\hline
\end{tabular}

a. Student $t$ statistic with 99 degrees of freedom.

b. Binomial sign test statistic with normal approximation.

c. Wilcoxon test statistic with normal approximation. 
TABLE 3

Pattern of Abnormal Returns: Results of Testing the Differential Roles of Joint Ventures for Hypothesis 2

CATEGORIES

\begin{tabular}{|c|c|c|c|c|}
\hline Test Statistics & $\begin{array}{l}\text { Identical } \\
(\mathrm{N}=91)\end{array}$ & $\begin{array}{l}\text { Related } \\
\text { Suppl. } \\
(\mathrm{N}=54)\end{array}$ & $\begin{array}{c}\text { Related } \\
\text { Complement } \\
(\mathrm{N}=73)\end{array}$ & $\begin{array}{c}\text { Unrelated } \\
(\mathrm{N}=17)\end{array}$ \\
\hline $\begin{array}{l}\text { Average } \\
\text { Abnormal } \\
\text { Return } \\
\text { (t-stat.) }\end{array}$ & $\begin{array}{l}1.32 \% \\
(5.20)^{* *}\end{array}$ & $\begin{array}{l}0.60 \% \\
(1.50)\end{array}$ & $\begin{array}{l}0.68 \% \\
(2.21)^{*}\end{array}$ & $\begin{array}{l}0.37 \% \\
(0.80)\end{array}$ \\
\hline $\begin{array}{l}\text { Firms with } \\
\text { Positive } \\
\text { Abnormal } \\
\text { returns } \\
\text { (Binomial z- } \\
\text { stat.) } \\
\text { Wilcoxon Test } \\
\text { (z-stat.) }\end{array}$ & $\begin{array}{l}62.6 \% \\
(2.41)^{* *} \\
3.15^{* *}\end{array}$ & $\begin{array}{c}53.7 \% \\
(0.54) \\
0.71\end{array}$ & $\begin{array}{l}57.5 \% \\
(1.29) \\
1.68^{+}\end{array}$ & $\begin{array}{c}52.9 \% \\
(0.24) \\
0.29\end{array}$ \\
\hline
\end{tabular}


TABLE 4

Pattern of Abnormal Returns: Results of Testing the Differential Effects of Relatedness with the Focal Parent's Portfolio for Hypothesis 3

\section{CATEGORIES}

\begin{tabular}{|c|c|c|c|}
\hline & $\begin{array}{c}\text { Full } \\
\text { Paired }\end{array}$ & $\begin{array}{l}\text { Parent-with- } \\
\text { Opportunity }\end{array}$ & $\begin{array}{l}\text { Parent-without- } \\
\text { Opportunity }\end{array}$ \\
\hline Test Statistics & $\begin{array}{l}\text { Sample } \\
(N=119)\end{array}$ & $\begin{array}{l}\text { Sample } \\
(\mathrm{N}=58)\end{array}$ & $\begin{array}{l}\text { Sample } \\
(\mathrm{N}=61)\end{array}$ \\
\hline $\begin{array}{l}\text { Two-Day } \\
\text { Announcement } \\
\text { Period Average } \\
\text { Abnormal Return } \\
\text { (t-stat.) }\end{array}$ & $\begin{array}{l}0.75 \% \\
(3.01)^{* *}\end{array}$ & $\begin{array}{l}1.40 \% \\
(3.79)^{* *}\end{array}$ & $\begin{array}{l}0.14 \% \\
(0.44)\end{array}$ \\
\hline $\begin{array}{l}\text { Firms with } \\
\text { Positive Abnormal } \\
\text { Returns }(\%) \\
\text { (Binomial z-stat.) } \\
\text { Wilcoxon Test } \\
\text { (z-stat.) }\end{array}$ & $\begin{array}{c}51.3 \% \\
(0.28) \\
0.36\end{array}$ & $\begin{array}{l}58.6 \% \\
(1.31) \\
1.71+\end{array}$ & $\begin{array}{c}44.3 \% \\
(-0.90) \\
-1.17\end{array}$ \\
\hline
\end{tabular}

$$
\begin{aligned}
& { }^{+} p<0.10 \\
& { }_{*} \mathrm{p} p<0.01
\end{aligned}
$$


TABLE 5

Pattern of Abnormal Returns: Differential Effects of Related versus Unrelated Partner For Testing Hypothesis 4

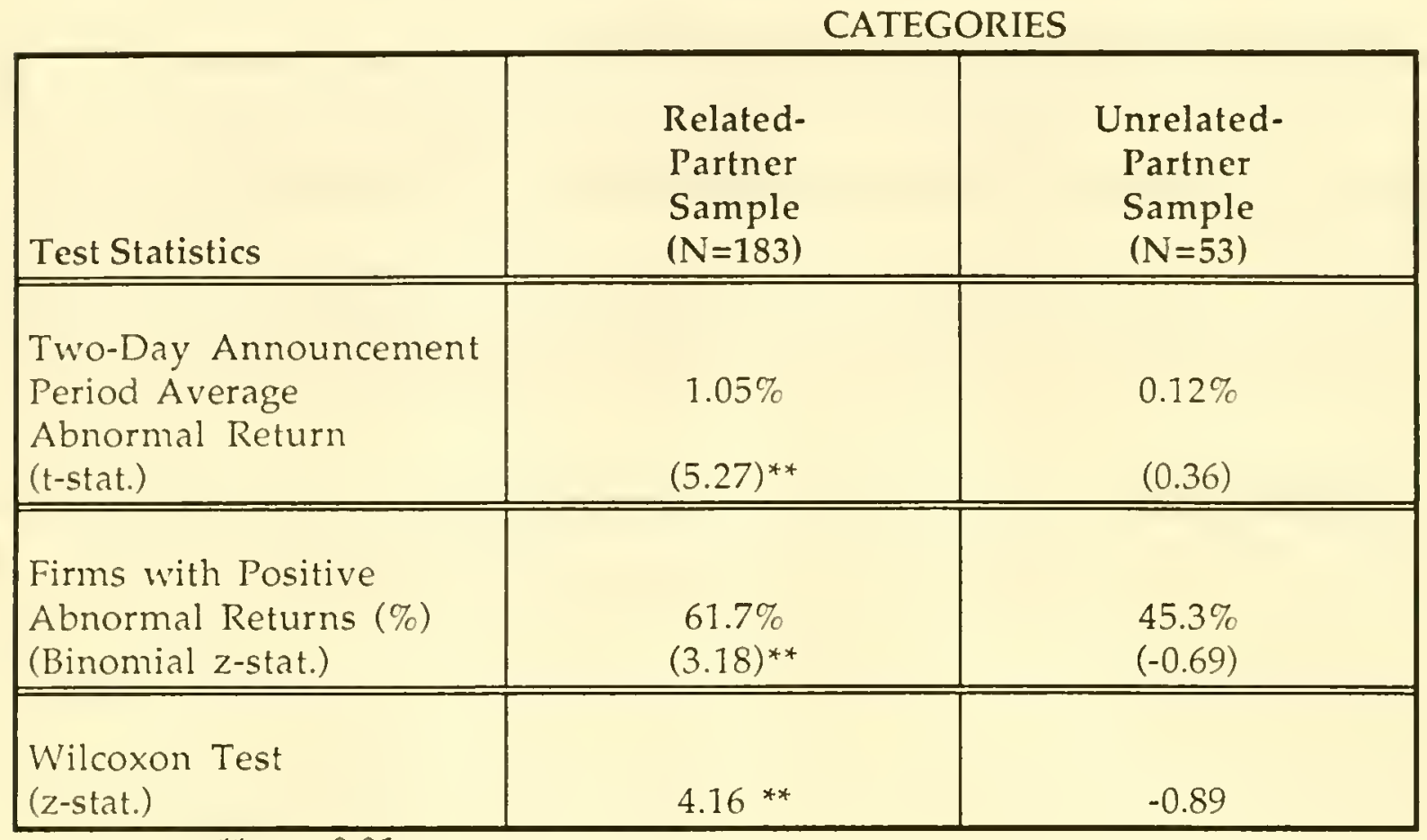

** $p<0.01$ 
TABLE 6:

Pattern of Abnormal Returns: Differential Effects of the Results Across

Large versus Small Partner for Hypothesis 5

CATEGORIES

\begin{tabular}{|c|c|c|c|c|}
\hline Test Statistics & $\begin{array}{l}\text { Full } \\
\text { Sample } \\
(\mathrm{N}=239)\end{array}$ & $\begin{array}{l}\text { Large } \\
\text { Partner } \\
\text { Sample } \\
(\mathrm{N}=59) \\
\end{array}$ & $\begin{array}{l}\text { Small } \\
\text { Partner } \\
\text { Sample } \\
(\mathrm{N}=60) \\
\end{array}$ & $\begin{array}{l}\text { All } \\
\text { Other } \\
\text { Sample } \\
(\mathrm{N}=120) \\
\end{array}$ \\
\hline $\begin{array}{l}\text { Two-Day } \\
\text { Announcement } \\
\text { Period Average } \\
\text { Abnormal } \\
\text { Return } \\
\text { (t-stat.) }\end{array}$ & $\begin{array}{l}0.876 \\
(5.28)^{* *}\end{array}$ & $\begin{array}{l}0.44 \% \\
(1.38) \\
\end{array}$ & $\begin{array}{l}1.13 \% \\
(3.18)^{* *}\end{array}$ & $\begin{array}{l}0.94 \% \\
(3.97)^{* *}\end{array}$ \\
\hline $\begin{array}{l}\text { Firms with } \\
\text { Positive } \\
\text { Abnormal } \\
\text { Returns (\%) } \\
\text { (Binomial z-stat.) }\end{array}$ & $\begin{array}{l}58.2 \% \\
(2.52)^{* *}\end{array}$ & $\begin{array}{l}39.7 \% \\
(-1.58) \\
\end{array}$ & $\begin{array}{l}62.7 \% \\
(1.96)^{*}\end{array}$ & $\begin{array}{l}64.8 \% \\
(3.26)^{* *}\end{array}$ \\
\hline $\begin{array}{l}\text { Wilcoxon Test } \\
\text { (z-stat.) }\end{array}$ & $3.30 * *$ & -1.95 & $2.45^{* *}$ & $4.26 * *$ \\
\hline $\begin{array}{l}\text { Gains in Dollar } \\
\text { (\$ Mil.) } \\
\text { Average Market } \\
\text { Value } \\
(\$ \text { Mil.) } \\
\text { Average Sales } \\
(\$ \text { Mil.) }\end{array}$ & $\begin{array}{l}\$ 12.6 \\
\$ 6,073 \\
\$ 8,227\end{array}$ & $\begin{array}{l}2.3 \\
10,010 \\
12,387\end{array}$ & $\begin{array}{l}19.2 \\
1,429 \\
2,367\end{array}$ & $\begin{array}{l}14.3 \\
6,489 \\
9,150\end{array}$ \\
\hline
\end{tabular}


FIGURE 1

Joint Ventures: Theoretical Perspectives and Research Focus

\begin{tabular}{|c|c|c|}
\hline Focus & Motives for JV Formation & Impacts of $\mathrm{JV}$ \\
\hline \multirow[t]{2}{*}{$\begin{array}{l}\text { Strategic } \\
\text { Behavior }\end{array}$} & $\begin{array}{l}\text { Type (A) } \\
\text { Explanation of JV formation } \\
\text { based on a firm's ability } \\
\text { to offer products or services } \\
\text { to compete effectiveley }\end{array}$ & $\begin{array}{l}\text { Type (B) } \\
\text { Expectation of higher performance } \\
\text { when firms form JVs to maximize } \\
\text { their ability to offer products or } \\
\text { services to compete effectively }\end{array}$ \\
\hline & $\begin{array}{l}\text { Empirical Studies: } \\
\text { Berg \& Friedman (1977) } \\
\text { Duncan (1982); }\end{array}$ & $\begin{array}{l}\text { Empirical Studies: } \\
\text { Harrigan (1988) } \\
\text { McConnell \& Nantell (1985) }\end{array}$ \\
\hline \multirow{2}{*}{$\begin{array}{l}\text { Transaction } \\
\text { Cost } \\
\text { Perspective }\end{array}$} & $\begin{array}{l}\text { Type (C) } \\
\text { Explanation of JV formation } \\
\text { based on minimization of } \\
\text { production and coordination } \\
\text { costs of governance }\end{array}$ & $\begin{array}{l}\text { Type (D) } \\
\text { Expectation of higher performance } \\
\text { when firms choose the modes } \\
\text { that best minimize f oduction } \\
\text { and coordination cos.s }\end{array}$ \\
\hline & $\begin{array}{l}\text { Empirical Studies: } \\
\text { Shan (1986); Teece, Pisano \& } \\
\text { Russo (1987) }\end{array}$ & No Empirical Study \\
\hline
\end{tabular}

Key:

Type A: $\quad$ Strategic Motives of Parents;

Type B: $\quad$ Effectiveness of JV strategies;

Type C: Efficient Governance Mechanisms;

Type D: Effectiveness of Governance Mechanisms. 
FIGURE 2

Role of Joint Ventures in Influencing

Product--Market Scope

(a) Role Clarification

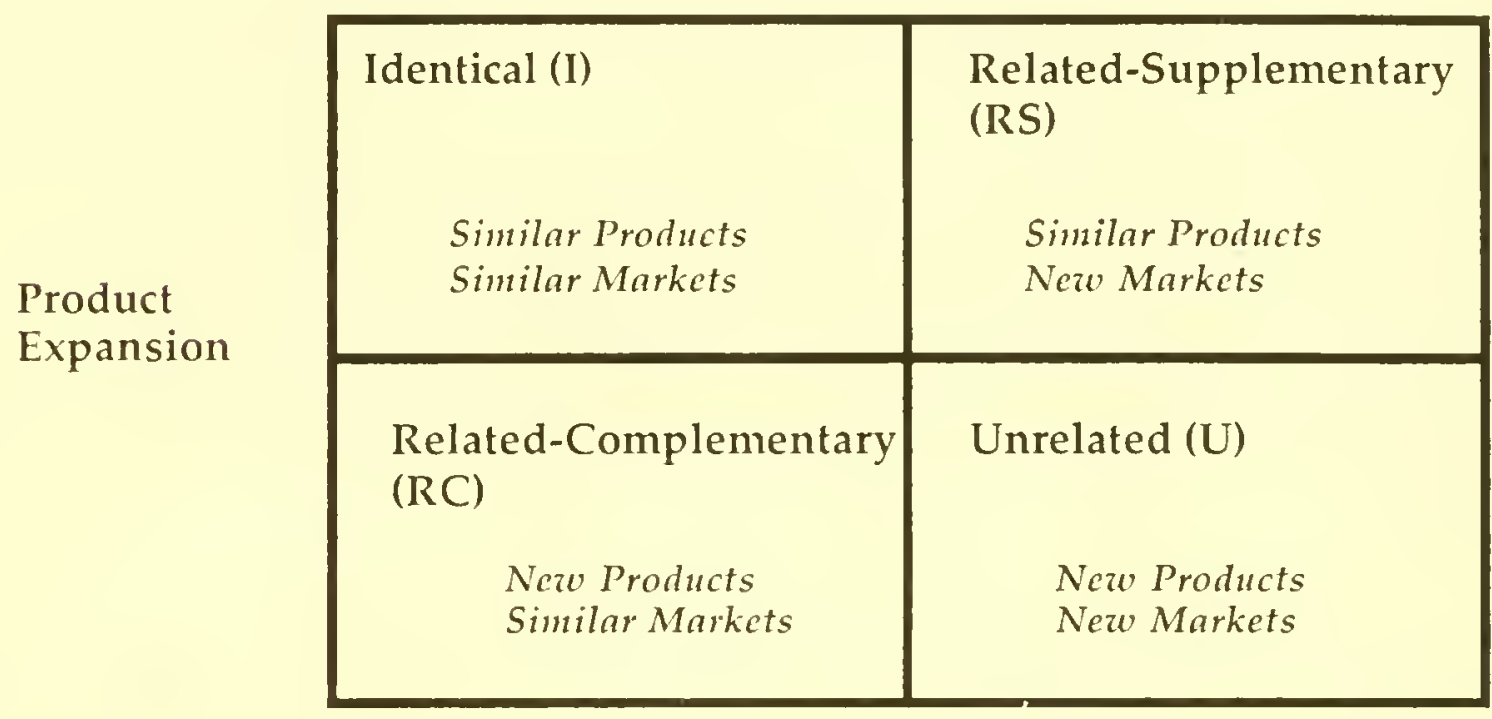

Market Expansion

(b) Illustrative Examples

\begin{tabular}{|l|l|l|c|c|}
\hline \multicolumn{1}{|c|}{ Parent 1 } & Parent 2 & Joint Venture & $\begin{array}{c}\text { Role for } \\
\text { Parent 1 }\end{array}$ & $\begin{array}{c}\text { Role for } \\
\text { Parent 2 }\end{array}$ \\
\hline Control Data & NCR & CPI & I & I \\
AT\&T & Ricoh & AT\&T Ricohb & RS & I \\
IBM & MCA & DiscoVisionc & RC & I \\
Warner Commun. & Amex & Warner-Amex d & I & U \\
$\begin{array}{l}\text { S. NE } \\
\text { Telephones }\end{array}$ & CSX & LightNete & I & U \\
\hline
\end{tabular}

a. to develop and make computer peripherals.

b. to make and market AT\&T's small telephone systems in Japan.

c. to develop, manufacture, and market videodisc players and their discs.

d. to construct and operate cable systems.

e. to launch railroad communication services. 


\section{Notes}

${ }^{1}$ Lewis (1990) provides an interesting set of case illustrations on the potential costs and difficulties to get unrelated partners to work together effectively.

2 No other distinguishing differences could be observed, thus providing support for the representativeness of this subsample in relation to the overall study sample.

3 We tested the robustness of this result by dividing the sample into large and small subsamples, but the coefficient was not statistically different across the subsamples.

4 For instance, a Financial Times article (June 10, 1986) reported that Ericsson invested $\$ 100$ million to modify one of its switching systems for the U.S. market; ITT invested $\$ 200$ million (20\% of its worldwide R\&D) to adapt a central office switch to the Lata Switching Generic Requirements of the U.S. market.

5 One of the reviewers pointed out that the relative share of the two parents in the JV is an important issue in understanding the differential opportunities. We agree with this observation entirely, and indeed in the $80 \%$ of the cases where the data were available, the split was 50-50, lending confidence to the assumption regarding equal share between the two parents. Further corroboration is provided by Berg \& Friedman (1980) and Harrigan (1985) who note that the majority of joint ventures are equally-owned, although their control structure may vary. In addition, in our questionnaire to obtain managerial assessments of JV performance, we asked them to indicate the ownership structure, and 52 out of 56 indicated that the JV was cqually-owned. 



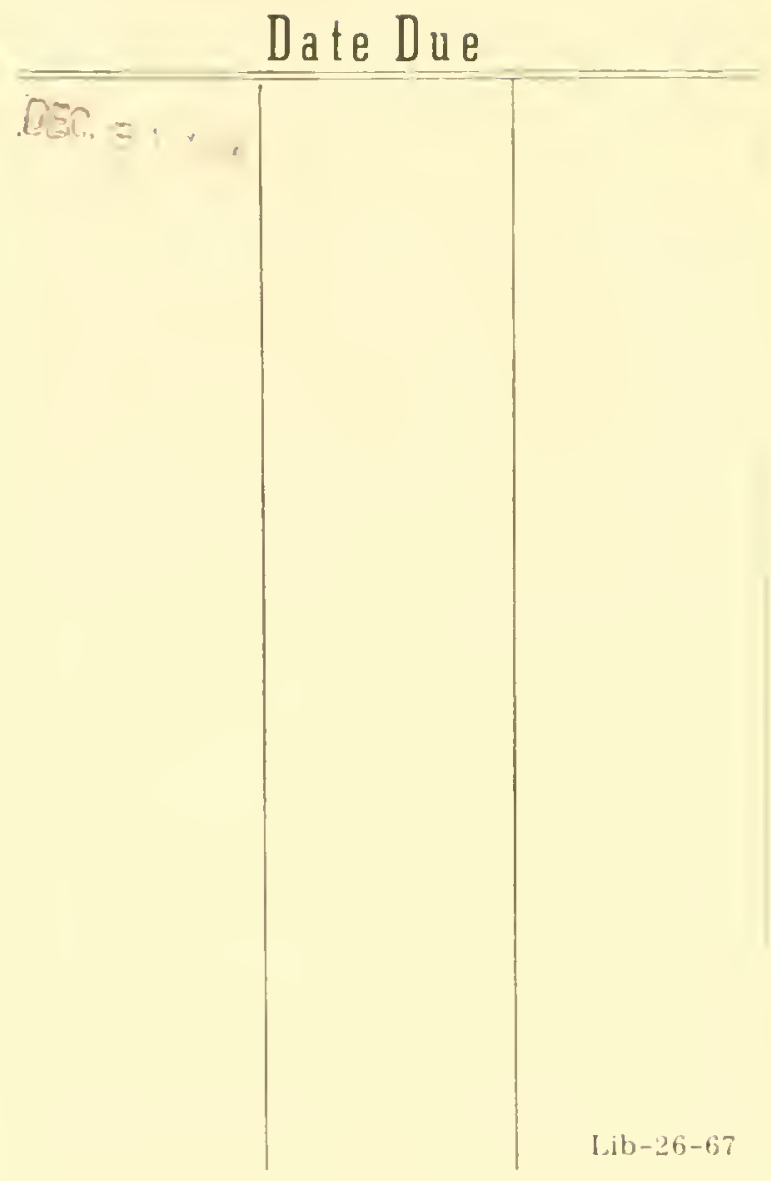




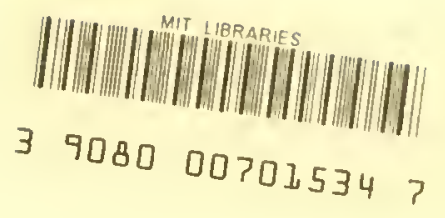


